\title{
Pengaruh Motivasi Intrinsik dan Knowledge Sharing terhadap Produktivitas Kerja Melalui Perilaku Innovatif Sebagai Variabel Intervening (Studi pada PT. BPR RUDO INDOBANK)
}

Manajemen

\author{
Andhy Tri Adriyanto $^{1 *}$, Agus Prasetyo ${ }^{2)}$ \\ Program Studi Manajemen Fakultas Ekonomi Universitas Semarang \\ *Email: andhy@usm.ac.id
}

\begin{abstract}
ABSTRAK
Penelitian tentang Pengaruh Motivasi Intrinsik dan Knowledge Sharing terhadap Produktivitas Kerja dengan Perilaku Inovatif sebagai Variable Intervening ini bertujuan untuk mengetahui pengaruh Pengaruh Motivasi Intrinsik dan Knowledge Sharing terhadap Produktivitas Kerja dengan Perilaku Inovatif sebagai Variable Intervening Lokasi penelitian PT. BPR Rudo Indobank di Kota Semarang. Populasi yang digunakan adalah Karyawan PT. BPR Rudo Indobank. Sampel yang ambil adalah 70 orang responden. Data penelitian berasal dari dua sumber yaitu data primer dan data sekunder. Jenis penelitian ini adalah kuantitatif. Pengambilan sampel menggunakan teknik sensus. Data yang terkumpul kemudian di analisa menggunakan Structural Equation Modelling (SEM) dengan software AMOS 24. Hasil penelitian ini Motivasi Intrinsik berpengaruh signifikan terhadap Perilaku Innovative, Knowledge Sharing berpengaruh signifikan terhadap Perilaku Innovative, Perilaku Innovative berpengaruh signifikan terhadap Produktivitas Kerja, Motivasi Intrinsik tidak berpengaruh signifikan terhadap Produktivitas Kerja, Knowledge Sharing berpengaruh signifikan terhadap Produktivitas Kerja. Hasil pengaruh mediasi variabel perilaku innovative dapat memediasi antara pengaruh motivasi intrinsik dan knowledge sharing terhadap produktivitas kerja.
\end{abstract}

Kata Kunci : Motivasi intrinsik, knowledge sharing, perilaku inovatif dan produktivitas kerja.

\section{ABSTRACT}

Research on the influence of intrinsic motivation and Knowledge Sharing to work productivity with innovative behaviors as a Variable Intervening is aimed at knowing the influence of intrinsic motivation and Knowledge Sharing influence on Working productivity with innovative behaviour as a Variable Intervening research site PT. BPR Rudo Indobank in Semarang City. The population used is the employee of PT. BPR Rudo Indobank. The sample taken was 70 respondents. Research data comes from two sources namely primary data and secondary data. This type of research is quantitative. Sampling using census techniques. The Data collected is then analyzed using Structural Equation Modelling (SEM) with AMOS 24 software. The results of this study intrinsic motivation significantly affect the Innovative behavior, Knowledge Sharing has significant effect on the Innovative conduct, Innovative behavior has significant effect on work productivity, intrinsic motivation has no significant effect on work productivity, Knowledge Sharing has significant effect on work productivity. The impact of innovative behavioral variable mediation can mediate between intrinsic motivational influences and knowledge sharing to work productivity. 
Keywords : Intrinsic Motivation, Knowledge Sharing, Innovative Behaviour and Working Productivity

\section{PENDAHULUAN}

Di era globalisasi saat ini membuat persaingan perilaku bisnis semakin ketat. Sudah menjadi kewajiban bagi pelaku bisnis untuk mendapatkan keunggulan bersaing sehingga agar memenangkan persaingan tersebut. Gunawan (2019) menyatakan bahwa setiap karyawan dituntut untuk dapat memberikan kontribusi positif melalui produktivitas kerja yang baik, mengingat produktivitas organisasi tergantung pada tinggi rendahnya produktivitas karyawannya.

Amri (2015) berpendapat bahwa produktivitas erat kaitannya dengan motivasi yang dapat dicerminkan oleh semangat kerja. Motivasi kerja memiliki peran besar dan penting untuk mencapai produktivitas karyawan yang diharapkan, karena motivasi dapat mendorong, membujuk, merangsang bahkan memaksa karyawan untuk bertindak dan bekerja sesuai yang diharapkan perusahaan (Gunawan, 2019).

Motivasi dan produktivitas juga erat kaitannya dalam tingkah laku karyawan, dimana motivasi karyawan yang meliputi kondisi intrinsik dan extrinsik akan memberikan dampak peningkatan produktivitas karyawan (Conlin-hurd, 2017). Perilaku inovatif sangat dipengaruhi oleh motivasi yang kuat dari karyawan, baik motivasi instrinsik maupun motivasi ekstrinstik yang dimiliki karyawan. Perilaku inovatif dapat pula dipahami sebagai perilaku dimana seseorang secara sukarela menyediakan akses terhadap orang lain mengenai inovasi dan pengalamannya (Patterson, 2014).
Afsar, Masood \& Umrani (2019) menyatakan bahwa organisasi harus dapat memanfaatkan adanya knowledge sharing behavior. karena hal ini akan memungkinkan karyawan untuk melakukan penyesuaian dalam pelaksanaan tugasnya. Pada studi lain, ditemukan bahwa knowledge sharing behavior memainkan peran penting untuk menampilkan perilaku kerja inovatif di perusahaan start-up di Malaysia (Munir \& Beh, 2019). Khorakian, Shahroodi, Jahangir, dan Nikkhah Farkhani (2019) tentang peran knowledge sharing behavior menyatakan bahwa dalam proses knowledge sharing behavior, ternyata perlu juga untuk melakukan pertukaran pengetahuan mengenai kesalahan yang pernah dilakukan selain menginformasikan tentang keberhasilan yang telah dicapai

Penelitian tentang motivasi intrinsik beberapa diantaranya menyatakan bahwa motivasi intrinsik memiliki pengaruh yang signifikan terhadap produktivitas kerja (Amri, 2015; Kiruja and Mukuru, 2013) hal ini bertentangan dengan hasil Utomo (2014) yang menyatakan bahwa motivasi mempunyai pengaruh negatif dan tidak berpengaruh signifikan terhadap produktivitas. Sedangkan penelitian tentang pengaruh knowledge sharing terhadap produktivitas kerja hasil diantaranya menyatakan bahwa knowledge sharing berpengaruh terhadap produktivitas kerja ( Aboelmaged, 2018; Blankenship dan Ruona, 2008) Namun hasil penelitian ini berbeda dengan hasil penelitian (Ryanet al., 2010; dan Kianto (2019) menyatakan bahwa knowledge sha- 
ring tidak berpengaruh terhadap produktivitas kerja.

Fenomena gap dalam penelitian ini adalah adanya penurunan produktivitas kerja yang mengindikasikan adanya motivasi intrinsic yang rendah, knowledge sharing yang rendah dan perilaku inovatif yang rendah yang berdampak pada produktivitas kerja yang rendah. PT. BPR Rudo Indobank Kota Semarang, tingkat kemangkiran pada tahun 2018 cukup tinggi. Akan tetapi pada tahun 2019 terjadi peningkatan keterlambatan dan kemangkiran yang signifikan dengan adanya kemangkiran ini akan terjadinya pengurangan jam kerja dari yang sudah ditentukan sehingga dapat menimbulkan penurunan produktivitas kerja karyawan PT. BPR Rudo Indobank

\section{KAJIAN PUSTAKA Produktivitas Kerja}

Teori-teori yang membahas tentang produktivitas kerja sangatlah bervariasi tetapi makna pokok dari produktivitas kerja adalah kemampuan seorang tenaga kerja dalam menghasilkan suatu pekerjaan. Menurut Hall, (2011) "produktivitas kerja adalah perbandingan antara output dengan input dimana output harus mempunyai nilai tambah dan teknik pengerjaannya yang lebih baik“. Menurut Siswadi (2016) produktivitas suatu sikap mental untuk menghasilkan sesuatu yang menyangkut dengan hasil akhir dari suatu pekerjaan yang didasarkan tingkat pelatihan dan disiplin kerja yang dimiliki oleh karyawan. Produktivitas adalah ukuran efisiensi produktif Suatu perbandingan antara hasil keluaran dan masukan (Kurnia et al,2019).

\section{Perilaku Innovatif}

Pada dasarnya untuk mendapatkan sumber daya manusia inovatif yang sesuai dengan kebutuhan diperlukan suatu strategi dalam mengelola sumber daya manusia. Perilaku inovatif karyawan mengacu pada sebuah kemampuan individu untuk menciptakan sebuah ide-ide dan sudut pandang baru, yang diubah menjadi inovasi (Dysvik, Kuvaas \& Buch, 2014). McGruirk, Lenihan dan Hart (2015) mendefinisikan perilaku kerja inovatif sebagai penciptaan model bisnis, teknik manajemen, strategi dan struktur organisasi diluar dari yang sudah ada. Sedangkan menurut Birdi, Leach, \& Magadley, (2016) Perilaku inovatif mengacu pada kemampuan untuk menciptakan sebuah ide yang original, menggunakan hasil kerja sebagai sebuah ide yang berpotensi dan menerapkan ide-ide baru kedalam praktek kerja.

\section{Motivasi Intrinsik}

Byron dan Khazanchy (2012) menyatakan bahwa motivasi intrinsik sangat mempengaruhi seseorang dalam mengembangkan kompetensinya yang berujung pada peningkatan kinerjanya. Motivasi yang muncul dari dalam diri individu (instrinsik) dapat berupa tanggung jawab, pengakuan, dan pengembangan. Menurut Cho et.al (2012) motivasi intrinsik merupakan suatu kemampuan untuk mengarahkan karyawan agar mau bekerja secara baik, sehingga tujuan karyawan dan tujuan perusahaan sama sama dapat tercapai. Perilaku dengan motivasi intrinsik adalah perilaku yang ditunjukkan untuk kepentingannya sendiri, dengan kata lain sumber motivasi biasanya datang dari penunjukkan perilaku itu sendiri. 


\section{Knowledge Sharing}

Knowledge sharing adalah proses dimana para individu saling mempertukarkan pengetahuan mereka. Knowledge dapat dipahami sebagai aset individu atau organisasi yang bersifat tacit maupun explicit. Explicit knowledge adalah knowledge yang telah terdokumentasikan, mudah dimodifikasi dan diartikulasikan serta bersifat objektif. Sebaliknya, tacit knowledge adalah knowledge yang belum terdokumentasikan dan melekat di dalam diri seseorang, tidak mudah untuk diungkapkan dan bersifat subjektif (Levin et al., 2014). Knowledge sharing terdiri atas bringing (knowledge donating) dan getting (knowledge collecting). Knowledge donating yaitu perilaku mengkomunikasikan modal intelektual yang dimiliki seseorang kepada yang lainnya dan knowledge collecting yaitu perilaku individu untuk berkonsultasi dengan individu lainnya mengenai modal intelektual yang dimiliki (Sutton, 2006).

\section{METODOLOGI PENELITIAN}

\section{Populasi dan Sampel}

a. Populasi

Populasi adalah Karyawan PT. BPR

Rudo Indobank di Kota Semarang Sebanyak 70 Karyawan

b. Sampel

Penggunaan seluruh populasi tanpa harus menarik sampel penelitian sebagai unit observasi disebut sebagai teknik sensus. Dari keseluruhan populasi diambil 70 orang responden

\section{Definisi Operasional dan Indikator}

\section{Motivasi Intrinsik (X1)}

Kumpulan proses psikologis yang memiliki kekuatan di dalam diri seseorang yang menyebabkan pergerakan, arahan, usaha, dan kegigihan dalam meng- hadapi rintangan untuk mencapai suatu tujuan, indikator Luthans (2011)
a. Keberhasilan
b. Pengakuan
c. Tanggung Jawab

\section{Knowledge Sharing (X2)}

Proses dimana para individu saling mempertukarkan pengetahuan mereka, Indikator Levin, et, al (2014)
a. Berbagi pengetahuan baru.
b. Berbagi informasi baru tentang pekerjaan
c. Perhatian kepada rekan kerja

\section{Perilaku Innovative (Y1)}

Sebagai perilaku dimana seseorang secara sukarela menyediakan akses terhadap orang lain mengenai inovasi dan pengalamannya, Indikator Galia (2007)
a. Ide baru
b. Cara baru
c. Teknik baru

\section{Produktivitas Kerja (Y2)}

Perbandingan antara output dengan input dimana output harus mempunyai nilai tambah dan teknik pengerjaannya yang lebih baik, Indikator Hall (2011)
a. Hasil kerja
b. Kualitas kerja
c. Kuantitas kerja

\section{Metode Analisis Data}

Analisis data adalah proses penyederhanaan data ke dalam bentuk yang lebih mudah dibaca diimplementasikan. Analisis data yang dilakukan dengan menggunakan the Structural Equation Model (SEM) dari paket software AMOS 24 dalam model dan pengujian hipotesis. Mustafa and Wijaya (2012) menyebutkan, SEM atau model persamaan structural adalah sebuah model statistik yang memberikan perkiraan perhi- 
tungan dari kekuatan hubungan hipotesis diantara variabel dalam sebuah model teoritis, baik secara langsung atau melalui variabel antara (intervening atau mediating).

\section{Hasil}

maka dapat diketahui pengaruh variabel Motivasi Intrinsik, Knowledge Sharing, Perilaku Innovatif terhadap variabel produktivitas kerja. Selain itu dapat diketahui pula pengaruh variabel perilaku innovative dalam memediasi pengaruh motivasi intrinsik terhadap produktivitas kerja dan pengaruh knowledge sharing terhadap produktivitas kerja Nilai estimasi koefisien jalur diketahui pada Standardized Regression Weights. Hasil analisis pengaruh masingmasing variabel secara keseluruhan disajikan pada Gambar 1 dan Tabel 1.
Pada bagian ini akan disajikan hasil pengujian hipotesis penelitian yang telah diajukan pada bab terdahulu. Pengujian hipotesis yang diajukan dalam penelitian ini dilakukan berdasarkan nilai Critical Ratio (CR) dari hubungan kausalitas hasil analisis SEM. Berdasarkan hasil estimasi,

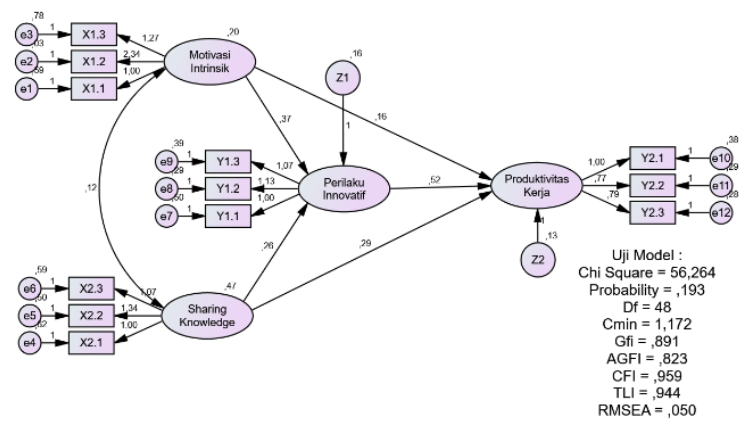

Gambar 1. Analisis Full Model SEM

Sumber: Program AMOS 22

Hasil uji terhadap kelayakan (goodness of fit) full model SEM untuk model penelitian ini dapat disajikan pada Tabel 1

Tabel 1. Hasil Pengujian Kelayakan Model Full Model

\begin{tabular}{lccc}
\multicolumn{1}{c}{$\begin{array}{c}\text { Indeks } \\
\text { Goodness of Fit }\end{array}$} & Kriteria & Nilai Estimasi & Keterangan \\
\hline Chi-Square $(\mathrm{df}=48)$ & Kecil $(<11,07)$ & 56.264 & Good \\
Probabilitas & $\geq 0,05$ & 0.193 & Good \\
CMIN/DF & $\leq 2,00$ & 1.172 & Good \\
GFI & $\geq 0,90$ & 0.891 & Marjinal \\
AGFI & $\geq 0,90$ & 0.823 & Marjinal \\
TLI & $\geq 0,95$ & 0.944 & Marjinal \\
CFI & $\geq 0,95$ & 0.959 & Good \\
RMSEA & $\leq 0,08$ & 0.050 & Good \\
\hline
\end{tabular}

Sumber : Hasil olah data, 2020

Hasil perhitungan indeks kesesuaian model pada Tabel 1 menunjukkan bahwa model ini sesuai menurut data atau fit terhadap data yang tersedia. Indeks CFI, TLI, CMINDF dan RMSEA terdapat pada rentang nilai yang diharapkan, yakni termasuk pada kategori baik. Indeks probabilitas chi-square diperoleh nilai 0,000 atau $<0,05$, sehingga pada kriteria tersebut kesesuaian tidak terpenuhi. Menurut Ghozali (2011) nilai chi-square sangat sensitif terhadap besarnya sampel. Apabila kriteria nilai chisquare tidak terpenuhi, maka dapat dilihat indeks yang lain.

Pada indeks GFI dan AGFI diperoleh hasil yang kurang baik, tetapi 
nilainya mendekati Cut off Value atau dapat dikatakan marjinal. Menurut Seguro, 2008 dalam Fitriyana, dkk. (2013), nilai marjinal menunjukkan kondisi kesesuaian model pengukuran di bawah kriteria ukuran fit, namun masih dapat diteruskan pada analisis lebih lanjut karena dekat dengan kriteria good fit, sehingga model dapat diterima. Dengan demikian, dapat disimpukan bahwa model penelitian ini memenuhi ukuran kesesuaian model (goodness of fit) dan dapat dilanjutkan pada analisis lebih lanjut, yaitu pengujian hipotesis.

Tabel 2. Hasil Estimasi Parameter

antar Variabel Berdasarkan Model SEM

\begin{tabular}{cllccc}
\hline No & Variabel Berpengaruh & Variabel Dipengaruhi & C.R & P & Ket \\
\hline 1 & Motivasi Intrinsik (X1) & Perilaku Innovative (Y1) & 2,234 & 0,025 & Sig. \\
2 & Knowledge Sharing (X2) & Perilaku Innovative (Y1) & 2,574 & 0,012 & Sig. \\
3 & Perilaku Innovative (Y1) & Produktivitas Kerja (Y2) & 4,134 & 0,000 & Sig. \\
& & & & & Tidak \\
4 & Motivasi Intrinsik (X1) & Produktivitas Kerja (Y2) & 0,762 & 0,446 & Sig. \\
5 & Knowledge Sharing (X2) & Produktivitas Kerja (Y2) & 2,177 & 0,030 & Sig. \\
\hline
\end{tabular}

Sumber : Hasil olah data, 2020

Berdasarkan pada hasil pengujian terhadap model keseluruhan dengan kriteria $\mathrm{CR} \geq 1,96$ dan $\mathrm{p}<0,05$, maka dapat dituliskan persamaan model matematik dalam bentuk Structural Equation Model (SEM) sebagai berikut :

$$
\begin{aligned}
& Y_{1}=0,374 X_{1}+0,258 X_{2}+\varsigma_{1} \\
& Y 2=0,374 X 1+0,258 X 2+0,518 Y 1+\varsigma 2
\end{aligned}
$$

Nilai koefisien determinasi atau $\mathrm{R}$ square (R2) dalam analisis sem dikenal dengan nilai square multiple correlation. Nilai tersebut dapat dijelaskan sebagai berikut:

a. Besarnya nilai squared multiple correlation pada persamaan pertama adalah 0,343 Nilai tersebut menunjukkan bahwa $34,3 \%$ dari variasi nilai perilaku innovatif dipengaruhi oleh variasi nilai variabel motivasi intrinsik dan knowledge sharing.

b. Besarnya nilai squared multiple correlation pada persamaan kedua adalah 0,707 . Nilai tersebut menunjukkan bah- wa $70,7 \%$ dari variasi nilai produktivitas kerja ditentukan oleh variasi nilai variabel motivasi intrinsik, knowledge sharing dan perilaku innovatif.

\section{Hasil Pengujian Hipotesis 1}

Berdasarkan hasil analisis dapat diketahui bahwa motivasi intrinsik berpengaruh positif dan signifikan terhadap perilaku innovatif karyawan. Hal ini dibuktikan dari nilai koefisien jalur sebesar 0,374 dan critical ratio (CR) sebesar 2,234 dengan probabilitas sebesar 0,025. Oleh karena nilai $\mathrm{CR} 2,234>1,96$ dan probabilitas $0,025<0,05$, maka dapat disimpulkan bahwa motivasi intrinsik berpengaruh positif terhadap perilaku innovatif. Artinya semakin tinggi motivasi intrinsik maka semakin tinggi pula perilaku inovatif.

\section{Hasil Pengujian Hipotesis 2}

Berdasarkan hasil analisis dapat diketahui bahwa knowledge sharing berpengaruh positif dan signifikan terhadap peri- 
laku innovatif karyawan. Hal ini dibuktikan dari nilai koefisien jalur sebesar 0,258 dan critical ratio (CR) sebesar 2,574 dengan probabilitas sebesar 0,012. Oleh karena nilai CR 2,574>1,96 dan probabilitas $0,012<0,05$, maka dapat disimpulkan bahwa knowledge sharing berpengaruh positif terhadap perilaku innovatif. Artinya semakin tinggi knowledge sharing maka semakin tinggi pula perilaku innovatif.

\section{Hasil Pengujian Hipotesis 3}

Berdasarkan hasil analisis dapat diketahui bahwa perilaku innovatif berpengaruh positif dan signifikan terhadap produktivitas kerja karyawan. Hal ini dibuktikan dari nilai koefisien jalur sebesar 0,518 dan critical ratio (CR) sebesar 4,134 dengan probabilitas sebesar 0,000. Oleh karena nilai CR 4,134>1,96 dan probabilitas $0,00<0,05$, maka dapat disimpulkan bahwa perilaku innovatif berpengaruh positif terhadap produktivitas kerja. Atinya semakin tinggi perilaku innovatif maka semakin tinggi pula produktivitas kerja.

\section{Hasil Pengujian Hipotesis 4}

Berdasarkan hasil analisis dapat diketahui bahwa motivasi intrinsik tidak berpengaruh dan signifikan terhadap produktivitas kerja karyawan. Hal ini dibuktikan dari nilai koefisien jalur sebesar 0,158 dan critical ratio (CR) sebesar 0,762 dengan probabilitas sebesar 0,446. Oleh karena nilai CR $0,762<1,96$ dan probabilitas $0,446>0,05$, maka dapat disimpulkan bahwa motivasi intrinsik tidak berpengaruh signifikan terhadap produktivitas kerja.

\section{Hasil Pengujian Hipotesis 5}

Berdasarkan hasil analisis dapat diketahui bahwa knowledge sharing berpengaruh positif dan signifikan terhadap produktivitas kerja karyawan. Hal ini dibuktikan dari nilai koefisien jalur sebesar 0,294 dan critical ratio (CR) sebesar 2,177 dengan probabilitas sebesar 0,030. Oleh karena nilai CR 2,177> $>$,96 dan probabilitas $0,030<0,05$, maka dapat disimpulkan bahwa knowledge sharing berpengaruh positif terhadap produktivitas kerja. Atinya semakin tinggi knowledge sharing maka semakin tinggi pula produktivitas kerja.

\section{Analisis Pengaruh Tidak Langsung}

Analisis pengaruh tidak langsung (indirect effect) dilakukan untuk mengetahui pengaruh variabel Motivasi Intrinsik dan Knowledge Sharing terhadap variabel Produktivitas Kerja melalui variabel intervening yaitu Perilaku Innovative. Menurut Ghozali (2011), pengujian pengaruh intervening dapat dilakukan menggunakan uji Sobel (Sobel Test). Berdasarkan hasil analisis tersebut, maka besarnya ringkasan pengujian pengaruh tidak langsung dapat disajikan pada tabel 3.

Tabel 3. Ringkasan Hasil Uji Sobel

\begin{tabular}{lccc}
\hline \multicolumn{1}{c}{$\begin{array}{c}\text { Variabel } \\
\text { Dipengaruhi }\end{array}$} & Koefisien & C.R & P \\
\hline $\begin{array}{l}\text { Motivasi Intrinsik }\left(\mathrm{X}_{1}\right) \text { Terhadap Produktivitas Kerja } \\
\left(\mathrm{Y}_{2}\right) \text { melalui intervening Perilaku Innovativ }\left(\mathrm{Y}_{1}\right)\end{array}$ & 0.154 & 1.965 & 0.049 \\
$\begin{array}{l}\text { Knowledge Sharing }\left(\mathrm{X}_{2}\right) \text { Terhadap Produktivitas Kerja } \\
\left(\mathrm{Y}_{2}\right) \text { melalui intervening Perilaku Innovativ }\left(\mathrm{Y}_{1}\right)\end{array}$ & 0.162 & 2.185 & 0.028 \\
\hline
\end{tabular}

Sumber : Hasil olah data, 2020 


\section{Hasil Pengujian Hipotesis 6}

Ada pengaruh yang signifikan antara variabel motivasi intrinsik terhadap produktivitas kerja melalui perilaku innovatif yang dibuktikan dengan nilai C.R adalah sebesar 1,965 dan nilai probabilitas 0,049. Dengan demikian, dapat disimpulkan bahwa perilaku innovatif menjadi perantara pengaruh motivasi intrinsik terhadap produktivitas kerja.

\section{Hasil Pengujian Hipotesis 7}

Ada pengaruh yang signifikan antara variabel knowledge sharing terhadap produktivitas kerja melalui perilaku inovatif yang dibuktikan dengan nilai C.R adalah sebesar 2,185 dan nilai probabilitas 0,028. Dengan demikian, maka dapat disimpulkan bahwa perilaku innovatif menjadi perantara pengaruh knowledge sharing terhadap produktivitas kerja.

Berdasarkan analisa jalur tersebut dapat diketahui bahwa jalur yang paling berpengaruh terhadap produktivitas kerja adalah jalur knowledge sharing terhadap produktivitas kerja melalui perilaku inovatif.

\section{Kesimpulan}

Berdasarkan hasil analisis yang telah dilakukan dapat diambil kesimpulan sebagai berikut:

1. Dari hasil pengujian hipotesis pertama diketahui bahwa variabel Motivasi Intrinsik berpengaruh signifikan terhadap Perilaku Innovative. Artinya hipotesis yang menyatakan ada pengaruh motivasi intrinsik terhadap Perilaku Innovative adalah diterima.

2. Dari hasil pengujian hipotesis kedua diketahui bahwa variabel Knowledge Sharing berpengaruh signifikan terhadap
Perilaku Innovative. Artinya hipotesis yang menyatakan ada pengaruh Knowledge Sharing terhadap Perilaku Inovative adalah diterima.

3. Dari hasil pengujian hipotesis ketiga diketahui bahwa variabel Perilaku Inovative berpengaruh signifikan terhadap Produktivitas Kerja. Artinya hipotesis yang menyatakan ada pengaruh Perilaku Inovative terhadap Produktivitas Kerja adalah diterima.

4. Dari hasil pengujian hipotesis keempat diketahui bahwa variabel Motivasi Intrinsik tidak berpengaruh signifikan terhadap Produktivitas Kerja. Artinya hipotesis yang menyatakan ada pengaruh Motivasi Intrinsik terhadap Produktivitas Kerja adalah ditolak.

5. Dari hasil pengujian hipotesis kelima diketahui bahwa variabel Knowledge Sharing berpengaruh signifikan terhadap Produktivitas Kerja. Artinya hipotesis yang menyatakan ada pengaruh Knowledge Sharing terhadap Produktivitas Kerja adalah diterima.

6. Dari hasil pengujian hipotesis keenam diketahui bahwa variabel Motivasi Intrinsik berpengaruh signifikan terhadap Produktivitas Kerja melalui Perilaku Innovative sebagai variabel intervening. Artinya hipotesis yang menyatakan ada pengaruh Motivasi Intrinsik terhadap Produktivitas Kerja melalui Perilaku Inovative sebagai variabel intervening adalah diterima.

7. Dari hasil pengujian hipotesis ketujuh diketahui bahwa variabel Knowledge Sharing berpengaruh signifikan terhadap Produktivitas Kerja melalui Perilaku Innovative sebagai variabel intervening. Artinya hipotesis yang menyatakan ada pengaruh Knowledge Sharing terhadap 
Produktivitas Kerja melalui Perilaku Innovative sebagai variabel intervening adalah diterima.

\section{Saran}

Berdasarkan hasil penelitian ini, saran yang dapat diberikan untuk meningkatkan Perilaku Innovative dan Produktivitas Kerja Karyawan PT. BPR Rudo Indobank adalah sebagai berikut:

1. Dari hasil analisis mengenai variabel Motivasi Intrinsik terdapat nilai indikator terendah adalah indikator pengakuan sebesar 3,40. Maka dalam hal ini untuk indicator pengakuan diharapkan pimpinan PT. BPR Rudo Indobank hendaknya memberikan apresiasi pengakuan terhadap karyawannya baik yang berprestasi maupun yang mempunyai progress pekerjaan yang baik.

2. Dari hasil analisis mengenai variabel Knowledge Sharing terdapat nilai indikator terendah adalah indikator berbagi informasi baru tentang pekerjaan sebesar 3,33. Maka dalam hal ini untuk indicator berbagi informasi baru tentang pekerjaan diharapkan pimpinan manajemen PT. BPR Rudo Indobank dapat menciptakan budaya berbagi informasi yang lebih baik sehingga dapat dicontoh oleh karyawan misal dengan menjalin hubungan antar karyawan dengan program kegiatan yang dapat menciptakan kebersamaan.

3. Dari hasil analisis mengenai variabel Perilaku Innovative terdapat nilai indikator terendah adalah indikator cara baru sebesar 3,67. Maka dalam hal ini untuk indicator cara baru diharapkan pimpinan manajemen PT. BPR Rudo Indo bank memberikan kesempatan yang baik bagi karyawan untuk menggunakan cara baru yang dianggap lebih sesuai dengan keinginan karyawan tersebut namun masih dalam batas ketentuan perusahaan.

4. Dari hasil analisis mengenai variabel Produktivitas Kerja terdapat nilai indikator terendah adalah indikator Hasil kerja sebesar 3,96. Maka dalam hal ini untuk indicator Hasil kerja diharapkan antara pimpinan dan karyawan PT. BPR Rudo Indo Bank Kota Semarang bisa mengadakan forum diskusi yang lebih intens terkait dengan hasil kerja yang disepakati bersama. Misal ketentuan dalam target pencapaian baik individu maupun target tim dan kriteria-kriteria tertentu.

\section{Keterbatasan Penelitian}

1. Penelitian ini masih terbatas pada satu kantor saja yaitu pada PT. BPR Rudo Indobank Kota Semarang sehingga hasil penelitian belum dapat digeneralisasikan dengan baik.

2. Jawaban responden kadang kurang konsisten terutama dalam pernyataan terbuka, sehingga kurang dapat memberikan gambaran yang sesungguhnya mengenai kondisi sebenarnya.

\section{Agenda Penelitian Mendatang}

Perlu mengidentiifikasi variabel intervening yang tepat untuk mendorong penguatan pengaruh motivasi intrinsik terhadap produktivitas kerja, seperti, dukungan dengan rekan sekerja (coworker support), komitmen dan sebagainya.

\section{DAFTAR PUSTAKA}

Aboelmaged, M. G. (2018). Knowledge sharing through enterprise social network (ESN) systems: motivational drivers and their impact on employees' productivity. Journal of Knowledge Management, 22(2), 362- 
383. https://doi.org/10.1108/JKM-052017-0188

Al-Busaidi, K. A., Olfman, L., Ryan, T., \& Leroy, G. (2008). The motivators and benefits of sharing knowledge to a KMS repository in an Omani organization. Innovation and Knowledge Management in Business Globalization: Theory and Practice Proceedings of the 10th International Business Information Management Association Conference, 1-2(April 2014), 928-935.

Blankenship, S., \& Ruona, W. E. (2008). Exploring Knowledge Sharing among Members of a Community of Practice. Online Submission, (2001).

Davoudi, Seyed Mehdi Mousavi, dan Kiarash Fartash, (2012), "The impact of knowledge sharing on organizational commitment of employees," Pacific Bussiness Review Internasional

Diah, A. A. S., \& Pramayani, I. (2018). Pengaruh Pemberdayaan, Perilaku Inovatif, dan Motivasi Kerja Terhadap Produktifitas Kerja Karyawan Bumbu Bali Restoran Tanjung Benoa Badung, Bali. INOBIS: Jurnal Inovasi Bisnis Dan Manajemen Indonesia, 2, 1-15.

Dur, Robert dan Robin Zoutenbier, 2014, "Instrinsic motivation of public sector employees," Iza Discussion Paper

Ghozali, Imam. 2017. Model Persamaan Struktural Konsep dan Aplikasi dengan Program AMOS 24 Update Bayesian SEM Edisi 7. Semarang: Universitas Diponegoro.

Hsiu Fen Lin, (2013), "Knowledge sharing and firm innovation capability: an empirical study," International Journal of Manpower

Jian, Zhaoquan; dan Chen Wang, (2013), "The impact of network competence, knowledge sharing on service innovation performance: moderating role of relationship quality," Journal of Industrial Engineering and
Management

Kirija, EK dan Elegwa Mukuru, 2013,"Effect of motivation on employee performance in Public Middle Level Technical Training Institutions in Kenya," International Journal of Advances in Managements and Economics

Kurnia, E., Daulay, R., \& Nugraha, F. (2019). Dampak Faktor Motivasi dan Fasilitas Kerja Terhadap Produktivitas Kerja Karyawan Pada Badan Usaha Milik Negara di Kota Medan. Jurnal Fakultas Ekonomi Dan Bisnis, 1(1), 365-372.

Lee, J., Kim, D., \& Sung, S. (2019). The effect of entrepreneurship on start-up open innovation: Innovative behavior of university students. Journal of Open Innovation: Technology, Market, and Complexity, 5(4). https://doi.org/10.3390/joitmc5040103

Levin, Daniel Z; Rob Cross; Lisa C Abrams; dan Eric L Lesser, (2014), "Trust and Knowledge sharing: A critical combination," IBM Institute for Knowledge Based Organizations

Megan Lee Endres; Steven P Endres; Sanjib K Chowdury; dan Intakhab Alam, (2007), "Tacit knowledge sharing, self efficacy theory and application to the open source community." Journal of Knowledge Management

Mustafa, Z dan Wijaya, T, 2012. Panduan Teknik Statistik SEM \& PLS dengan SPSS AMOS. Cahaya Atma Pustaka, Yogyakarta

Nasir, N., Halimatussakdiah, H., Suryani, I., Zuhra, S. E., Armia, S., \& Mahdani, M. (2018). How Intrinsic Motivation and Innovative Work Behavior Affect Job Performance. Advances in Social Science, Education and Humanities Research, 292(Agc), 606-612“'. https://doi.org/10.2991/agc18.2019.91

Nguyen, T. P. L., Tran, N. M., Doan, X. H., 
\& Van Nguyen, H. (2018). The impact of knowledge sharing on innovative work behavior of Vietnam telecommunications enterprises employees. Asian Journal of Multidisciplinary Studies, 10(1), 5362. https://doi.org/10.5267/j.msl.2019.8.0 16

Rhodin, Roni; Titik Kismiyati; Tri Margono, (2014), "Implementasi knowledge sharing sebagai upaya peningkatan efektifitas ke profesionalan pustakawan," STAIN

Robbins, Stephen. 2008. Perilaku Organisasi. Prentice Hall. PT Indeks Kelompok Gramedia.Edisi Bahasa Indonesia.Edisi Kesepuluh

Torabi, F., \& El-Den, J. (2017). The impact of Knowledge Management on Organizational Productivity: A Case Study on Koosar Bank of Iran. Procedia Computer Science, 124, 300

310.https://doi.org/10.1016/j.procs.20 17.12.159

Utomo, Cipto. 2014. Pengaruh Kepemimpinan Motivasi Kerja, Disiplin Kerja dan Lingkungan Kerja Terhadap Produktivitas Kerja Karyawan Jurnal Politik, Vol. 1, No. 1 